\title{
PENAMBAHAN LISIN PADA PAKAN KOMERSIAL TERHADAP LAJU PERTUMBUHAN, RASIO KONVERSI PAKAN DAN EFISIENSI PAKAN UDANG GALAH (Macrobrachium rosenbergii)
}

\section{Addition of Lysine at Commercial Feed for Growth, Feed Conversion Ratio and Feed Efficiency of Prawns (Macrobrachium rosenbergii)}

\author{
Andy Pramana ${ }^{1 *}$, Agustono $^{2}$ dan Tri Nurhajati ${ }^{3}$. \\ ${ }^{1}$ Program Studi Budidaya Perairan, Fakultas Perikanan dan Kelautan, Universitas Airlangga, Surabaya \\ ${ }^{2}$ Departemen Manajemen Kesehatan Ikan dan Budidaya Perairan, Fakultas Perikanan dan Kelautan, Universitas \\ Airlangga, Surabaya \\ *andy-p--fpk10.web.unair.ac.id
}

\begin{abstract}
Abstrak
Produksi nasional udang galah (Macrobrachium rosenbergii) di Indonesia hanya sekitar 400.000 ton hanya untuk memenuhi kebutuhan pasar domestik yang belum terpenuhi. Salah satu upaya untuk meningkatkan produksi dan produktivitas kegiatan budidaya udang air tawar dapat dilakukan dengan pengembangan pakan alternatif atau feed additive yang dapat mempercepat pertumbuhan sehingga memperpendek masa produksi. Lisin merupakan salah satu feed additive yang berperan dalam pembentukan karnitin. Karnitin berpengaruh pada pertumbuhan dan oksidasi lemak dalam udang. Penelitian ini bertujuan untuk mengetahui pengaruh penambahan lisin pada pakan komersial terhadap laju pertumbuhan, rasio konversi pakan dan efisiensi pakan udang galah (Macrobrachium rosenbergii). Perlakuan pada penelitian ini adalah pakan komersial tanpa penambahan lisin, pakan komersial dengan penambahan 0,5\%, pakan komersial dengan penambahan $1 \%$, pakan komersial dengan penambahan 1,5 \% dan pakan komersial dengan penambahan $2 \%$. Penelitian ini menggunakan metode eksperimental dengan Rancangan Acak Lengkap (RAL). Analisa statistik menggunakan Analisis Varian (ANAVA) untuk mengetahui pengaruh perlakuan. Hasil penelitian menunjukkan bahwa penambahan lisin pada pakan komersial tidak berbeda nyata $(\mathrm{p}>0,05)$ dari tingkat pertumbuhan, rasio konversi pakan dan efisiensi pakan udang galah (Macrobrachium rosenbergii). Kebutuhan protein dan lisin dalam udang galah belum terpenuhi sehingga laju pertumbuhan relatif lambat. Kualitas air udang media pemeliharaan oksigen terlarut 6,9-7,3 ppm, pH 7-8, suhu 29-30 ${ }^{\circ} \mathrm{C}$ dan amonia 0-0,25 mg / l.
\end{abstract}

Kata kunci: Lisin, Udang Galah dan Pakan

\begin{abstract}
National production of freshwater prawn (Macrobrachium rosenbergii) in Indonesia is only about 400,000 tons just to meet domestic market needs unfulfilled. One of the efforts to increase the production and productivity of freshwater prawn farming activities can be done with the development of alternative feed or feed additive that can accelerate growth thereby shortening the production period. Lysine is one addictive feeds which have a role in the formation of carnitine. Carnitine effect on growth and fat oxidation in shrimp. This research determine the effect of lysine on commercial diets on the rate of growth, feed conversion ratio and feed efficiency of freshwater prawn (Macrobrachium rosenbergii). The treatments were commercial feed without the addition of lysine, commercial feed with the addition of $0.5 \%$, commercial diets with the addition of $1 \%$, commercial diets with the addition of $1.5 \%$ and a commercial feed with the addition of $2 \%$, the experimental method used in this study with randomized design complete (RAL). Statistical analysis using analysis of variants (ANOVA) to determine the effect of treatment. Based on the results of research showed that the addition of lysine to the commercial feed was not significantly different ( $>>0.05$ ) on growth rate, feed conversion ratio and feed efficiency of freshwater prawn (Macrobrachium rosenbergii). Need for protein and lysine in freshwater prawn have not been fulfilled so that the rate of growth is relatively slow. Water quality maintenance medium prawns are dissolved oxygen 6.9 - 7.3 ppm, pH 7-8, temperature 29-30 ${ }^{\circ} \mathrm{C}$, , and ammonia 0-0.25 mg / l.
\end{abstract}

Keywords: Lysine, Freshwater Prawn and Feed 


\section{PENDAHULUAN}

Produksi nasional budidaya udang galah (Macrobrachium rosenbergii) di Indonesia baru sekitar 400.000 ton hanya untuk memenuhi kebutuhan pasar dalam negeri yang belum terpenuhi. Harga jual udang galah (Macrobrachium rosenbergii) di pasar dalam negeri rata-rata mencapai Rp 75.000/kg. Sementara di pasar ekspor, harganya bisa mencapai Rp 90.000/kg (Solo Pos, 2013). Untuk memenuhi kebutuhan udang galah diperlukan pengembangan budidaya udang galah.

Peningkatan produksi dan produktivitas udang galah dari kegiatan budidaya dapat dilakukan dengan antara lain penggunaan induk unggul, manajemen induk yang benar, perbaikan sistem produksi benih, pengembangan pakan alternative atau feed additive pakan yang dapat mempercepat pertumbuhan sehingga memperpendek masa produksi (Aliah $d k k$, 2012). Salah satu feed additive yang dapat diberikan pada pakan untuk udang adalah asam amino esensial berupa lisin (Gatlin, D. M. and Peng Li. 2008).

Lisin merupakan asam amino esensial yang berperan untuk pertumbuhan udang (Millamena et al, 1998). Lisin berperan dalam pembentukan karnitin. Karnitin diperlukan dalam proses metabolisme lemak untuk membentuk atau menghasilkan energi, dimana karnitin berperan dalam transportasi asam lemak rantai panjang ke dalam mitokondria (Biswas et al., 2006).

Menurut Fengjun et al. (2012) juga mengindikasikan bahwa penambahan 1,515\% lisin dari jumlah pakan dapat meningkatkan pertumbuhan udang puti (Litopenaeus vannamei). Penambahan 1\% lisin dari jumlah pakan dapat meningkatkan efisiensi pemanfaatan protein oleh udang windu (Penaeus monodon) yang diikuti peningkatan laju pertumbuhan (Biswas et al, 2006). Berdasarkan pada latar belakang diatas maka dilakukan penelitian penambahan lisin pada pakan komersial terhadap laju pertumbuhan, rasio konversi pakan dan efisiensi pakan udang galah (Macrobrachium rosenbergii).

Berdasarkan pada latar belakang diatas maka dilakukan penelitian penambahan lisin pada pakan komersial terhadap laju pertumbuhan, rasio konversi pakan dan efisiensi pakan udang galah (Macrobrachium rosenbergii).

\section{METODOLOGI}

\section{Waktu dan Tempat}

Penelitian ini telah dilakukan mulai bulan April 2014 sampai Mei 2014 di Laboratorium Pendidikan Perikanan, Fakultas Perikanan dan Kelautan, Universitas Airlangga.

\section{Materi Penelitian}

Peralatan Penelitian

Peralatan yang digunakan pada penelitian ini meliputi akuarium ukuran $15 \times 15 \times 25 \mathrm{~cm}^{3}$, aerator kecil, selang aerasi, batu aerasi, seser, timbangan analitik, gelas ukur, $\mathrm{pH}$ meter, DO meter, termometer air dan amonia test kit.

\section{Bahan Penelitian}

Hewan uji yang digunakan dalam penelitian adalah benih udang galah yang berasal dari Balai Benih Udang Galah Prigi. Udang galah (PL 20) yang digunakan memiliki berat berkisar 0.06-0,1 gram. Media pemeliharaan yang digunakan dalam penelitian ini adalah air tawar dengan volume 1,5 liter per akuarium. Asam amino lisin yang akan digunakan adalah L-lysine-HCl.

\section{Metode Penelitian}

Metode penelitian yang digunakan dalam penelitian ini adalah metode eksperimental dengan lima perlakuan. Penelitian ini membandingkan pengaruh antara perlakuan $\mathrm{P}_{0}, \mathrm{P}_{1}, \mathrm{P}_{2}, \mathrm{P}_{3}$, dan $\mathrm{P}_{4}$ terhadap laju pertumbuhan, rasio konversi pakan dan efisiensi pakan udang galah (Macrobrachium rosenbergii).

Perlakuan $\mathrm{P}_{0}$ : pakan komersial tanpa penambahan lisin. 
Perlakuan $\mathrm{P}_{1}$ : 98,5 \% pakan komersial + $1 \%$ tepung tapioka $+0,5 \%$ lisin.

Perlakuan $\mathrm{P}_{2}$ : $\quad 98 \quad \% \quad$ pakan komersial $+1 \%$ tepung tapioka $+1 \%$ lisin.

Perlakuan $\mathrm{P}_{3}$ : 97,5 \% pakan komersial + $1 \%$ tepung tapioka $+1,5 \%$ lisin.

Perlakuan $\mathrm{P}_{4}$ : $\quad 97 \quad \% \quad$ pakan komersial $+1 \%$ tepung tapioka $+2 \%$ lisin.

\section{Prosedur Kerja}

Persiapan penelitian dengan membersihkan peralatan yang akan digunakan. Peralatan berupa akuarium, tong plastik, baskom, seser dan terpal dicuci menggunakan sabun dan dibilas kemudian dikeringkan. Aklimatisasi tokolan udang galah dilakukan selama 3 hari. Kemudian dipuasakan selama 1 hari untuk menghilangkan pengaruh pakan sebelumnya. Media pemeliharaan yang akan digunakan adalah air tawar. Air tawar tersebut diisikan sebanyak 1,5 L ke dalam 20 akuarium. Padat tebar udang galah 1 ekor/0,15 L. Masing-masing akuarium berisi 10 ekor udang galah.

Pakan diberikan dalam bentuk powder yang berasal dari pakan komersial dengan penambahan lisin dan binder. Komposisi bahan pakan disesuaikan dengan dosis lisin tiap perlakuan. Komposisi bahan penyusun pakan dapat dilihat pada Tabel 1.

Tabel 1. Bahan penyusun pakan

\begin{tabular}{cccccc}
\hline Komposisi & \multicolumn{5}{c}{ Perlakuan } \\
\cline { 2 - 6 }$\left(100 \mathrm{~g}^{-1}\right)$ & $\mathrm{P}_{0}$ & $\mathrm{P}_{1}$ & $\mathrm{P}_{2}$ & $\mathrm{P}_{3}$ & $\mathrm{P}_{4}$ \\
\hline Pakan & 100 & 78,5 & 78 & 77,5 & 77 \\
Komersial & & & & & \\
\hline $\begin{array}{c}\text { Tepung } \\
\text { Tapioka }\end{array}$ & - & 21 & 21 & 21 & 21 \\
\hline Lisin & - & 0,5 & 1 & 1,5 & 2 \\
\hline
\end{tabular}

Tepung tapioka ini digunakan sebagai binder. Hal ini bertujuan ketika pakan udang diberikan, lisin yang terkandung didalamnya tidak larut dalam air dan dapat dimanfaatkan untuk sintesa protein tubuh (Alam et al., 2005). Sebelum digunakan sebagai binder, $0,5 \mathrm{~g}$ tepung tapioka dimasak dengan $100 \mathrm{ml}$ air sambil diaduk hingga menjadi adonan yang mengental. Adonan tepung tapioka dibagi menjadi dua bagian. Lisin ditimbang sesuai dosis tiap perlakuan kemudian dicampur dengan $6 \mathrm{~g}$ adonan tepung tapioka. Campuran tersebut kemudian dicampur dengan pakan komersial, serta ditambahkan dengan 15 g adonan tepung tapioka. Penggunaan jumlah binder yang cukup banyak dikarenakan agar lisin dapat terlapisi sempurna dan tercampur merata pada pakan komersial. Setelah semua bahan tercampur, kemudian pakan dikeringkan pada oven dengan suhu $40^{\circ} \mathrm{C}$. Setelah pakan tersebut kering, diremahkan sampai menjadi bentuk flake (Richard et al, 2009). Pakan pada tiap perlakuan yang telah jadi dilakukan analisa proksimat untuk mengetahui kandungan nutrisinya.

Pada proses pemeliharaan udang galah dilakukan manajemen kualitas air dengan cara menyifon kotoran dan sisa pakan setiap hari pada pukul 15.00 WIB, serta dilakukan pergantian air sebanyak $50 \%$ saat penyifonan. Udang galah diberi perlakuan selama 28 hari. Pemberian pakan dilakukan sebanyak $3 \mathrm{kali} / \mathrm{hari}$ pada pukul 06.00, 16.00, dan 21.00 WIB. Jumlah pakan yang diberikan sebanyak $10 \%$ dari biomass udang galah (Anh et al, 2009). Jumlah pakan yang diberikan ditentukan setiap 7 hari, dilakukan perhitungan biomass dengan cara penimbangan bobot seluruh populasi udang galah.

\section{Analisa Data}

Hasil dari pengukuran kualitas air dan penghitungan prevalensi endoparasit pada ikan nila (O. niloticus) akan ditampilkan dalam bentuk tabel dan gambar. Data dari kualitas air dan prevalensi endoparasit akan dianalisis menggunakan korelasi regresi.

\section{HASIL DAN PEMBAHASAN}

Diterima/submitted:4 November 2017 Disetujui/accepted:3 Juli 2017 
Rata-rata laju pertumbuhan udang

galah terdapat pada Tabel 2.

Tabel 2. Rata-rata laju pertumbuhan (g/hari) udang galah

\begin{tabular}{ccc}
\hline Perlakuan & $\begin{array}{c}\text { Laju Pertumbuhan } \\
\text { (g/hari) } \pm \text { SD }\end{array}$ & Transformasi $\sqrt{ } \mathrm{y}+0,5 \pm \mathrm{SD}$ \\
\hline $\mathrm{P}_{0}$ & $0.044 \pm 0.00708$ & $0.738 \pm 0.00482$ \\
\hline $\mathrm{P}_{1}$ & $0.046 \pm 0.00434$ & $0.739 \pm 0.00293$ \\
\hline $\mathrm{P}_{2}$ & $0.047 \pm 0.00328$ & $0.74 \pm 0.00222$ \\
\hline $\mathrm{P}_{3}$ & $0.05 \pm 0.00905$ & $0.741 \pm 0.00611$ \\
\hline $\mathrm{P}_{4}$ & $0.052 \pm 0.00746$ & $0.74 \pm 0.00500$ \\
\hline
\end{tabular}

Keterangan:

$\mathrm{P}_{0}=$ pakan komersial tanpa penambahan lisin, $\mathrm{P}_{1}=98,5 \%$ pakan komersial $+1 \%$ tepung tapioka + 0,5\% lisin, $\mathrm{P}_{2}=98 \%$ pakan komersial $+1 \%$ tepung tapioka $+1 \%$ lisin, $\mathrm{P}_{3}=97,5$ $\%$ pakan komersial $+1 \%$ tepung tapioka $+1,5 \%$ lisin, $\mathrm{P} 4=97 \%$ pakan komersial $+1 \%$ tepung tapioka $+2 \%$ lisin. SD $=$ standart deviasi.

Hasil analysis of variance (ANOVA) menunjukan bahwa penambahan lisin pada pakan komersial menunjukkan hasil yang tidak berbeda nyata
( $>00,05)$ terhadap laju pertumbuhan tiap perlakuan. Rata-rata laju pertumbuhan spesifik udang galah terdapat pada Tabel 3.

Tabel 3. Rata-rata laju pertumbuhan spesifik (\%) udang galah

\begin{tabular}{ccc}
\hline Perlakuan & $\begin{array}{c}\text { Laju Pertumbuhan } \\
\text { Spesifik (\%) } \pm \mathrm{SD}\end{array}$ & Transformasi $\sqrt{\mathrm{y} \pm \mathrm{SD}}$ \\
\hline $\mathrm{P}_{0}$ & $3.19 \pm 0.53701$ & $1.78 \pm 0.15354$ \\
\hline $\mathrm{P}_{1}$ & $3.32 \pm 0.39023$ & $1.82 \pm 0.10931$ \\
\hline $\mathrm{P}_{2}$ & $3.36 \pm 0.25339$ & $1.83 \pm 0.06884$ \\
\hline $\mathrm{P}_{3}$ & $3.40 \pm 0.58332$ & $1.84 \pm 0.16132$ \\
\hline $\mathrm{P}_{4}$ & $3.65 \pm 0.27494$ & $1.91 \pm 0.07340$ \\
\hline
\end{tabular}

Keterangan:

$\mathrm{P}_{0}=$ pakan komersial tanpa penambahan lisin, $\mathrm{P}_{1}=98,5 \%$ pakan komersial $+1 \%$ tepung tapioka $+0,5 \%$ lisin, $\mathrm{P}_{2}=98 \%$ pakan komersial $+1 \%$ tepung tapioka $+1 \%$ lisin, $\mathrm{P}_{3}=97,5$ $\%$ pakan komersial $+1 \%$ tepung tapioka $+1,5 \%$ lisin, $\mathrm{P} 4=97 \%$ pakan komersial $+1 \%$ tepung tapioka $+2 \%$ lisin. SD = standart deviasi.

Hasil analysis of variance (ANOVA) menunjukan bahwa penambahan lisin pada pakan komersial menunjukkan hasil yang tidak berbeda nyata
( $>>0,05)$ terhadap laju pertumbuhan spesifik tiap perlakuan. Rata-rata rasio konversi pakan udang galah terdapat pada Tabel 4 .

Tabel 4. Rata-rata rasio konversi pakan udang galah

\begin{tabular}{ccc}
\hline Perlakuan & $\begin{array}{c}\text { Rasio Konversi Pakan } \\
\pm \mathrm{SD}\end{array}$ & Transformasi $\sqrt{\mathrm{y} \pm \mathrm{SD}}$ \\
\hline $\mathrm{P}_{0}$ & $1.54 \pm 0.394518$ & $1.23 \pm 0.15391$ \\
\hline $\mathrm{P}_{1}$ & $1.48 \pm 0.169103$ & $1.21 \pm 0.06818$ \\
\hline $\mathrm{P}_{2}$ & $1.46 \pm 0.104409$ & $1.21 \pm 0.04247$ \\
\hline
\end{tabular}




\begin{tabular}{ccc}
\hline $\mathrm{P}_{3}$ & $1.45 \pm 0.23432$ & $1.20 \pm 0.09721$ \\
\hline $\mathrm{P}_{4}$ & $1.42 \pm 0.143546$ & $1.19 \pm 0.06052$ \\
\hline
\end{tabular}

Keterangan:

$\mathrm{P}_{0}=$ pakan komersial tanpa penambahan lisin, $\mathrm{P}_{1}=98,5 \%$ pakan komersial $+1 \%$ tepung tapioka $+0,5 \%$ lisin, $\mathrm{P}_{2}=98 \%$ pakan komersial $+1 \%$ tepung tapioka $+1 \%$ lisin, $\mathrm{P}_{3}=97,5$ $\%$ pakan komersial $+1 \%$ tepung tapioka $+1,5 \%$ lisin, $\mathrm{P} 4=97 \%$ pakan komersial $+1 \%$ tepung tapioka $+2 \%$ lisin. SD $=$ standart deviasi.

Hasil analysis of variance (ANOVA) menunjukan bahwa penambahan lisin pada pakan komersial menunjukkan hasil yang tidak berbeda nyata
( $>>0,05)$ terhadap rasio konversi pakan tiap perlakuan. Rata-rata efisiensi pakan udang galah terdapat pada Tabel 5 .

Tabel 5. Rata-rata efisiensi pakan (\%) udang galah

\begin{tabular}{|c|c|c|}
\hline Perlakuan & Efisiensi Pakan (\%) \pm SD & $\begin{array}{c}\text { Transformasi } \arcsin \sqrt{ } \mathrm{y} \\
\text { SD }\end{array}$ \\
\hline $\mathrm{P}_{0}$ & $67.74 \pm 15.054577$ & $55.81 \pm 9.64238$ \\
\hline $\mathrm{P}_{1}$ & $68.41 \pm 7.196205$ & $55.87 \pm 4.36986$ \\
\hline $\mathrm{P}_{2}$ & $68.69 \pm 4.588617$ & $55.99 \pm 2.78599$ \\
\hline $\mathrm{P}_{3}$ & $70.51 \pm 11.367146$ & $57.43 \pm 7.39100$ \\
\hline $\mathrm{P}_{4}$ & $71.09 \pm 7.314211$ & $57.57 \pm 4.72632$ \\
\hline
\end{tabular}

Keterangan:

$\mathrm{P}_{0}=$ pakan komersial tanpa penambahan lisin, $\mathrm{P}_{1}=98,5 \%$ pakan komersial $+1 \%$ tepung tapioka $+0,5 \%$ lisin, $\mathrm{P}_{2}=98 \%$ pakan komersial $+1 \%$ tepung tapioka $+1 \%$ lisin, $\mathrm{P}_{3}=97,5$ $\%$ pakan komersial $+1 \%$ tepung tapioka $+1,5 \%$ lisin, $\mathrm{P} 4=97 \%$ pakan komersial $+1 \%$ tepung tapioka $+2 \%$ lisin. SD = standart deviasi.

Hasil analysis of variance (ANOVA) menunjukan bahwa penambahan lisin pada pakan komersial menunjukkan hasil yang tidak berbeda nyata $(p>0,05)$ terhadap efisiensi pakan tiap perlakuan. Laju pertumbuhan berfungsi untuk menghitung pertumbuhan berat udang per hari. Hasil uji statistik menunjukkan pemberian pakan dengan penambahan lisin tidak mempengaruhi laju pertumbuhan udang galah $(\mathrm{p}>0,05)$. Hal ini disebabkan karena pada masing-masing pakan perlakuan jumlah kandungan lisin belum memenuhi kebutuhan lisin udang galah. Jumlah lisin dalam pakan perlakuan sekitar $0,782 \%$ sampai $1,183 \%$ sedangkan menurut Anh et al., (2009) kebutuhan lisin bagi udang galah sebesar $1,65 \%$ dari jumlah pakan.
Laju pertumbuhan spesifik berfungsi untuk menghitung persentase pertumbuhan berat udang per hari. Hasil uji statistik menunjukkan pemberian pakan dengan penambahan lisin dengan tidak mempengaruhi laju pertumbuhan spesifik udang galah $(\mathrm{p}>0,05)$. Hal ini disebabkan karena kebutuhan protein udang galah belum terpenuhi sehingga laju pertumbuhan spesifiknya relatif lambat. Jumlah protein dalam pakan perlakuan sekitar 27,414 \% sampai 31,221 \%. sedangkan menurut SNI (2006) kebutuhan protein benih udang galah sebesar min $32 \%$.

Nilai rasio konversi pakan perlakuan adalah $1,4: 1$ sampai $1,5: 1$. Hal ini sesusai dengan peryataan Sim dkk. (2005) menyatakan ikan yang diberikan pakan buatan mempunyai nilai rasio konversi pakan 1 : 1 hingga 2 : 1 . Adanya pakan 
yang tidak tercerna atau jenis pakan yang kurang disukai merupakan faktor penyebab rasio konvesi pakan tinggi (Sutarmat, 2006). Pemberian pakan yang berlebihan menyebabkan nilai rasio konversi pakan tinggi karena banyak sisa pakan yang berada di akuarium.

Menurut Hariati (1989), tingkat efisiensi penggunaan pakan terbaik dapat dicapai pada nilai perhitungan konversi pakan terendah. Efisiensi pakan berfungsi untuk mengetahui mutu pakan ikan yang terbaik pada setiap perlakuan kombinasi pakan selama penelitian. Rata-rata efisiensi pakan meningkat seiring dengan meningkatnya nilai protein dan lisin dalam pakan udang galah. Hal ini sesuai dengan pendapat Huet (1970) dalam Amalia $d k k$ (2013) yang menyatakan bahwa efisiensi pakan yang tinggi menunjukkan penggunaan pakan yang efisien sehingga hanya sedikit protein yang dirombak untuk memenuhi kebutuhan energi dan selebihnya digunakan untuk pertumbuhan.

\section{KESIMPULAN DAN SARAN Kesimpulan}

Pemberian pakan dengan penambahan lisin tidak meningkatkan laju pertumbuhan dan efisiensi pakan, serta tidak menurunkan nilai rasio konversi pakan udang galah.

\section{Saran}

Berdasarkan hasil penelitian yang telah dilakukan, perlu dilakukan penelitian lebih lanjut mengenai efektivitas penambahan lisin dengan dosis lebih dari $2 \%$ dalam pakan komersial terhadap udang galah (Macrobrachium rosenbergii).

\section{DAFTAR PUSTAKA}

Alam, Md. S., S. Teshima, S. Koshio, M. Ishikawa, O. Uyan, L. H. H. Hernandez and F. R. Michael. 2005. Supplemental Effects of Coated Methionine and/or Lysine to Soy Protein Isolate Diet for Juvenile Kuruma Shrimp
(Marsupenaeus

japonicus).

Aquaculture 248. (13-19). 6 p.

Aliah, R. S., Kusmiyati, Sutanti, K. M. Dewi, dan Suratna. 2012. Diseminasi dan Difusi Teknologi Produksi Udang Galah Unggul (Macrobrachium rosenbergii) Di Kabupaten Sleman, Yogyakarta. Pusat Teknologi Produksi Pertanian. Badan Pengkajian dan Penerapan Teknologi.

Amalia, R., Subandiyono., dan E. Arini. 2013. Pengaruh Penggunaan Papain Terhadap Tingkat Pemanfaatan Protein Pakan dan Pertumbuhan Lele Dumbo (Clarias garepinus). Journal of Aquaculture Management and Technologi. Volume 2, Nomor 1. Hal 136-143

Anh, N.T.N., T. T. Hien., W. Mathieu., N. V. Hoa and P. Sorgeloos. 2009. Effect of Fishmeal Replacement with Artemia Biomass as a Protein Source in Practical Diets for The Giant Freshwater Prawn (Macrobrachium rosenbergii). Aquaculture Research 40 (669-680). 11 p.

Biswas, P., A. K. Pal., N. P. Sahu., A. K. Reddy., A. K. Prusty and S. Misra. 2006. Lysine and/or phytase supplementation in the diet of Penaeus monodon (Fabricius) juveniles: Effect on growth, body composition and lipid profile. Aquaculture 265 (253-260). 7 p.

Fengjun, Xie., Wenping, Zeng., Qicun, Zhou., Hualang, Wang., Tuo, Wang., Changqu, Zheng and Yongli, Wang. 2012. Dietary Lysine Requirement Of Juvenile Pacific White Shrimp, Litopenaeus Vannamei. Aquaculture 358-359. (116-121). $6 \mathrm{p}$.

Gatlin, D. M. and Peng Li. 2008. Use of Diet Additives to Improve Nutritional Value of Alternative Protein Source. In : Lim, C., C. D. Webster and Lee, C (Eds). Alternative Protein Sources in Aquaculture Diets. The Haworth 
Press, Taylor \& Francis Group. New York. pp. 501-522

Hariati, A. M. 1989. Makanan Ikan. Diktat Kuliah Universitas Brawijaya. Malang.

Kusriningrum, R. S. 2008. Perancangan Percobaan. Universitas Airlangga. Surabaya. hal. 43-63.

Millamena, O. M., M. N. Bautista-Teruel, O. S. Reyes and A. Kanazawa. 1998. Requirements of Juvenile Marine Shrimp (Penaeus monodon Fabricius) for Lysine and Arginine. Aquaculture 164. (95-104). 9 p.

Richard, L., P. P. Blanc., V. Rigolet., S. J. Kaushik and I. Geurden. 2009. Maintenance and growth Requirements for Nitrogen, Lysine and Methionine and Their Utilisation Efficiencies in Juvenile Black Tiger Shrimp (Penaeus monodon) Using a Factorial Approach. British Journal of Nutrition (2010). 103 (984-995). 13 p.

Sim, S., Rimmer M., Williams K., Toledo J. D., Sugama K., Rumengan I., dan Phillips M, L., 2005. Pedoman Praktis Pemberian dan Pengelolaan Pakan untuk Kerapu. Australian Centre for International Agricultural Research. Australia. Pub. No. 2005 - 02. 25 hal.

Solo Pos. 2013. Produksi Nasional Budidaya Udang Galah Masih Minim. http://www.solopos.com [7 Januari 2013].

Standar Nasional Indonesia (SNI) 012724-1992. 1992. Pakan Buatan bagi Udang. Badan Standarisasi Nasional. Jakarta. 13 hal.

Sutarmat, T. 2006. Studi Pendahuluan Pemeliharaan Ikan Kakap Merah dalam KJA dengan Ukuran Tebar yang Berbeda. Prosiding Konferensi Akuakultur Indonesia. Hal 193-197. 